The 16th Economic International Conference

New Challenges and Opportunities for the Economy 4.0, May 7-8th, 2020, Suceava, Romania

\title{
Low Touch Economy and Social Economy in Rural Heritage Rich Communities Impacted by COVID-19 Crisis
}

\author{
Anamaria BUCACIUC, Gabriela PRELICEAN, \\ Carmen CHAŞOVSCHI
}

https://doi.org/10.18662/lumproc/ncoe4.0.2020/36

How to cite: Bucaciuc, A., Prelicean, G., \& Chaşovschi, C. (2020). Low Touch Economy and Social Economy in Rural Heritage Rich Communities Impacted by COVID-19 Crisis. In C. Nastase (vol. ed.), Lumen Proceedings: Vol. 13. 16th Economic International Conference NCOE 4.02020 (pp. 398-409). Iasi, Romania: LUMEN Publishing House.

https://doi.org/10.18662/lumproc/ncoe4.0.2020/36 


\title{
Low Touch Economy and Social Economy in Rural Heritage Rich Communities Impacted by COVID-19 Crisis
}

\author{
Anamaria BUCACIUC ${ }^{1 *}$, Gabriela PRELICEAN², \\ Carmen CHAȘOVSCHI ${ }^{3}$
}

\begin{abstract}
While rural communities have always struggled with factors like marginalisation, low entrepreneurial development, high unemployment, low education and poor health services, the COV ID-19 crisis brings extra pressure by reducing close-contact interactions and by introducing travel and bygiene restrictions. Cultural heritage has represented for many rural communities a competitive advantage in their economic development, either already exploited or seen as an opportunity. The problem of this process in the new COVID-19 context is represented by a demand and supply shock, caused by the stop of direct labour, high decrease of acquisitions and cease of travel. In these new economic and social circumstances, it is important to explore the way the COVID19 crisis impacts rural heritage rich communities and which are possible further actions in order to ensure a return to dynamic social and economic interactions. The present paper will bring into focus the concepts of Low Touch Economy and Social Economy as a support in dealing with these new economic and social conditions and will prospect possible intertwining between the two. Presented as a literature review and an exploration, the paper brings into focus the brand new concept of Low Touch Economy presented by Board of Innovation, a business design and innovation strategy firm located in Netherlands.
\end{abstract}

Keywords: Rural heritage; social economy; low touch economy; COVID-19 crisis.

\footnotetext{
${ }^{1}$ Faculty of Economics and Public Administration, "Stefan cel Mare" University, Suceava, Romania, anamaria.bucaciuc@usm.ro.

${ }^{2}$ Faculty of Economics and Public Administration, "Stefan cel Mare" University, Suceava, Romania, prelipceang@usm.ro.

${ }^{3}$ Faculty of Economics and Public Administration, "Stefan cel Mare" University, Suceava, Romania, carmenc@,usm.ro.

* Corresponding author.
} 
Anamaria BUCACIUC, ... | Lumen Proceedings 13 | NCOE4.0 2020

\section{Introduction}

In January 2020, the International Monetary Fund launched a world economic outlook report [1] forecasting a rise of global growth from $2.9 \%$ in 2019 to $3.3 \%$ in 2020 and 3.4 percent for 2021. These affirmations had as base a series of factors like the bottoming out of global trade and manufacturing economy, positive perspectives on the US-China trade negotiations, decrease of chances for a no-deal Brexit. The few foreseen turning points in global macroeconomic data were grounded mainly on the rise of geopolitical tensions, shifts in the financial markets and weather related disasters. Topics like marginalisation, low entrepreneurial development, high unemployment, low education and poor health services were the main threats for rural communities [2].

While states and worldwide organizations were planning their futures, a cluster of severe pneumonia cases, based on a novel strain of coronavirus, were identified in Wuhan, Hubei province, China. Further, these cases lead to a worldwide spread [3] the declaration of SARS-CoV-2 virus and the disease COVID-19 a Public Health Emergency of International Concern on January 30, 2020 and a global pandemic on March 11, 2020 [4]. This lead to a severe health crisis, closure of severe protective measures in agriculture, closure of schools, factories, businesses, travel restrictions in most countries and even free movement limitations even in the same city of domicile in some countries worldwide.

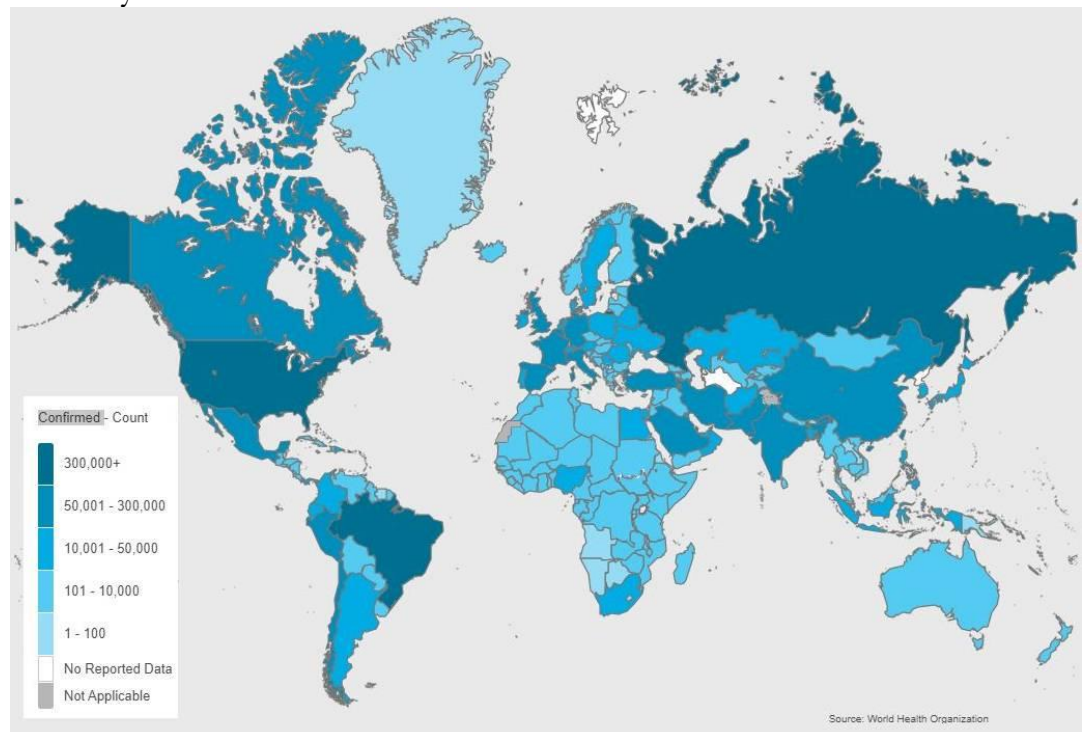

Figure 1. Choropleth map representing the number of COVID-19 cases worldwide, on 2020/06/01. Source: World Health Organization. 
The post COVID-19 economy of 2020 will have to combine traditional elements like technological innovation, globalisation, and demographic shifts with new ones like travel restrictions, remote work, limited gatherings and hygiene requirements.

The present theoretical article refers to new and established concepts related to the social and economic resilience of rural heritage rich communities in time of the COVID-19 crisis.

\section{Theoretical Background}

This chapter includes an overview of the scientific literature, reports and overviews in the field of the rural economic transformation during the COVID-19 crisis. The research gap is represented by the novelty of the presented concept of Low Touch Economy, and thus by the deficiency in its scientific analysis. The article brings extra value in the economic research through its exploration of a brand new concept in the narrow space of rural heritage rich communities in the COVID-19 time and its possible intertwining with social economy.

\subsection{Rural Heritage Rich Communities during COVID-19 Crisis}

In 2018, the European Economic and Social Committee presented an opinion regarding the contribution of Europe's rural areas to the 2018 Year of Cultural Heritage [5]. Thus, rural areas were considered to contain the greatest cultural heritage through their natural landscapes, geological structures and the human imprints visible in built settlements and landscape alterations like the ones in agriculture, forestry and the use of lakes and rivers. Also, rural culture was considered to be created by people in a reflective manner of their work, interests and social challenges. Over time, their economic activity changes: some crafts evolve, while others tend to disappear through modernization and changes in the consumer's behaviour.

Rural communities are usually a combination of traditional and modern social values, each of these giving advantages and disadvantages in what concerns their social and economic development.

Meanwhile, rural communities are faced [6], [7] with multiple threats, like marginalization, low entrepreneurial development, demographic change and low education. On the other side, rural communities can benefit from a series of opportunities like unique characteristics, tourism potential, "back to rural" movement, open education. These can boost local economic and social development even in time of crisis. 


\section{Threats}



Low entrepreneurial
development

Demographic change

\section{Low education}

\section{Opportunities}

\section{Unique character}

Tourism

"Back to rural" movement

\section{Open education}

Figure 2. Threats and opportunities characteristic to rural communities. Source: Authors own elaboration.

During the COVID-19 pandemic, some characteristics of rural areas like physical distance, low density of the population and its relative isolation offered advantages in responding to central health crisis regulations. A representation of physical distance in a Romanian village can be seen in Figure 3. Elders in quarantine time in Comana village, Giurgiu, Romania. Source: HotNews.ro [8]. However, these rural communities are not at safe guard from the risk of COVID-19, since they are much less prepared: $80 \%$ of the 734 million extreme poor registered previously to the pandemic live in rural areas. The main risks are caused by poor health services, low education, lack of internet, low social protection and infrastructure [9].

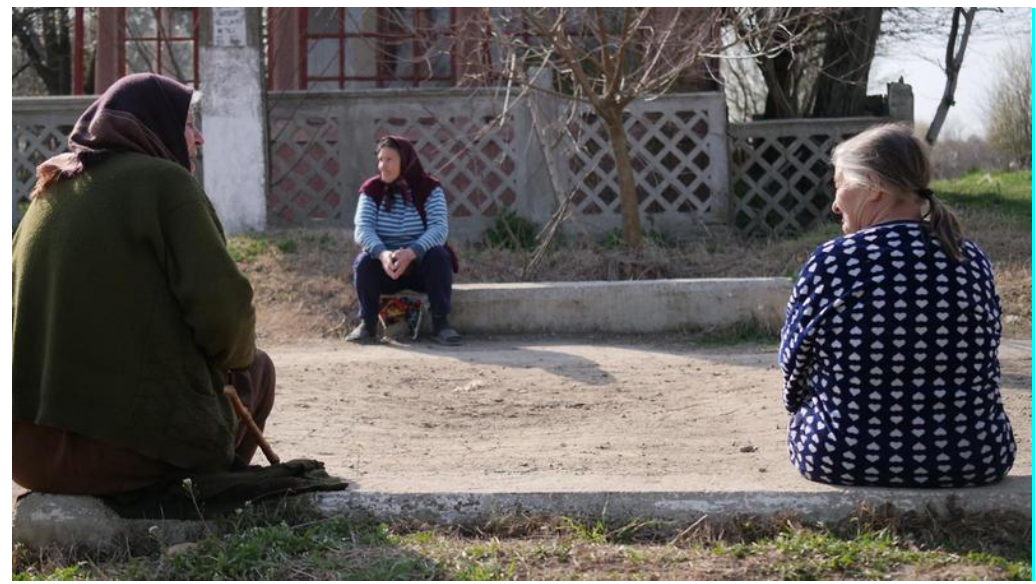

Figure 3. Elders in quarantine time in Comana village, Giurgiu, Romania. Source: HotNews.ro. 
All these factors combined with central state decisions fighting with COVID-19 pandemic have led to a series of factors impacting the rural market [10]:

- disruption of the agricultural supply-chain,

- delay in sowing and harvesting of crops,

- job cuts in all economic sector,

- complete shutdown of exports and travel,

- shutdown/confinement of small industry units, businesses/traders, and shops,

- weak consumption trend post COVID-19.

In this harsh context, rural communities rich in heritage objectives suffer even more, since a part of their economic activity as relying on tourism or commerce with traditional products, both sectors being massively hit by quarantine measures and changes in consumer behaviour.

\subsection{Social Economy in the Context of COVID-19}

Social economy is a topic that has generated controversy among both academics and practitioners. According to Mendell [11], one can even observe a different interpretation of the concept at the level of countries, which adopt variations of the term and definitions. Thus, the United States has chosen to equate the social economy with the non-profit sector, and only more recently has it included income-generating social enterprises. On the other hand, there are several interpretations in Europe, the broadest being that of the European Union which places the social economy in the enlarged political economy and allows a better understanding of the integration of market, non-market and non-monetary resources of the social economy, in a similar way to the public and private sector. In developing countries, the activities of the social economy intertwine with those of the solidarity economy, targeting in particular non-market activities and being associated with the informal sector. All these differences have broadened the meaning of what we call the social economy, allowing the understanding of the term as a strategy to democratize the economy but also as an organizational and legal form that includes cooperatives, non-profits and private enterprises with socio-economic objectives or social purpose.

In the literature, the social economy is defined as the economic interval that unites the private sector, the generator of income, and the public sector, where economic activities with community purposes are carried out [12]. 
In the context of COVID-19 pandemic, the potential of social economy might support the economic and social recovery through their reinvention while showing resilience and social commitment [13].

This is the example of countless social economy organizations worldwide that shifted their activity to responding to the new needs triggered by the new crisis. Social economy organizations started producing masks and personal protection equipment for the health system and for citizens, adapted their sales strategy to home delivery or started volunteering in order to address disparities caused by the quarantine measures.

\subsection{The New Concept of Low Touch Economy}

The concept of Low Touch Economy has been introduced by Board of Innovation, a business design and innovation strategy firm located in Netherlands, as a response to the crisis generated by COVID-19 pandemic which is expected to last at least until late 2021. It addresses the way business sectors around the globe have to operate in times of restrictions and high stress. It is defined by a conglomerate of characteristics like [14]:

- Implementation of policies regarding low touch, limitation of gatherings, restriction of travels, in order to mitigate health risks;

- New regulations in the global markets, changes in the consumer behavior and supply chain disruptions;

- Adaptation of business models to the current health and social requirements.

The Low Touch Economy starts with the premises that the course of the following years will be set by how the COVID-19 crisis is managed at a micro and macro level. The social physical distancing and hygiene regulations will affect all terms the consumers and the economy as a whole. Moreover, while the long awaited solution to the entire crisis, a vaccine, is expected to hit the market only in 18 to 24 months, there is the need to redesign the value exchanged between consumers and suppliers.

\begin{tabular}{|c|c|c|c|c|c|}
\hline & & Direct impa & $\begin{array}{l}\text { IMPACT ON YOU } \\
\text { of Covid-19/ Indirect impact }\end{array}$ & $\begin{array}{l}\text { ORGANISATION } \\
\text { f economic recession / Abili: }\end{array}$ & o adapt fast \\
\hline & & $\begin{array}{l}\text { Positive } \\
\text { Revenue growth through } \\
\text { demand surge } \\
\text { e.g. E-commerce }\end{array}$ & $\begin{array}{l}\text { Mildly negative } \\
\text { Sustained revenue loss of } \\
0-15 \% \text { in } 02-42020 \\
\text { e.g. Consumer Goods }\end{array}$ & $\begin{array}{c}\text { Severe } \\
\text { Sustained revenue loss of } \\
15-50 \% \text { in } 02.42020 \\
\text { e.g. Oil and gas }\end{array}$ & $\begin{array}{c}\text { Catastrophic } \\
\text { Sustained revenue loss of } \\
+50 \% \text { in } 02-42020 \\
\text { e.g. Tourism }\end{array}$ \\
\hline 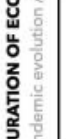 & $\begin{array}{l}1.5 \text { year impact } \\
\text { U-curve recovery; Social } \\
\text { distance measurements } \\
\text { prolonged, economic } \\
\text { stimulus eases damage }\end{array}$ & $\begin{array}{l}\text { Push for growth and } \\
\text { market share }\end{array}$ & $\begin{array}{l}\text { Defend, improve } \\
\text { competitive position, } \\
\text { and find new growth }\end{array}$ & $\begin{array}{l}\text { Pivot through organic } \\
\text { innovation and inorganic } \\
\text { growth, or divest }\end{array}$ & $\begin{array}{l}\text { Pivot through organic } \\
\text { innovation and inorganic } \\
\text { growth, or divest }\end{array}$ \\
\hline
\end{tabular}

Figure 4. Low Touch Economy framework. Source: Board of Innovation. 
The model proposed by Board of Innovation for this redesign process consists of a 4 step plan:

1. Assessment of the impact on the whole industry, on the supply chain, on the consumers and not lest on the society.

2. Development of a strategy based on the Low Touch Economy framework (Figure 4. Low Touch Economy framework. Source: Board of Innovation).

3. Initiation of an offence based on pivoting opportunities and innovation pipeline.

4. Making it happen by adopting an agile work model based on remote teams, adapted/renewed business model, engaged growth lead.

While the uncertain future will reveal itself, entrepreneurs can use the Low Touch Economy model to seize the different opportunities that might appear.

\section{Argument of the paper}

The paper supports the thesis that rural heritage rich communities will have to intertwine the distinctive elements of low touch economy and social economy in order to fight the effects produced by COVID-19 pandemic.

Theoretical analyses, investigation of applied organizational models of intertwining economic models and empirical thinking will create understanding of how existing tools can be used in order to fight new crisis and it will even lead to new models better adapted to the time's needs.

\section{Arguments to support the thesis}

Rural heritage rich communities have dealt even before COVID-19 crisis with different challenges that made them not being able to take advantage of their potential. In 2017, Eurostat was noting that touristic packages of rural-cultural objectives connected with health and recreational activities would be a major bridge between urban people and rural communities [5]. Also, a triggering factor in establishing this bridge was the "back to rural" movement which in the context of quarantine measures imposed during the pandemic has highly escalated.

Travel restrictions, home isolation and remote working are all factors that on short and medium term will encourage local rural tourism and the development of new economic activities. These activities will be the ones developed by people coming from urban areas, wishing the benefits of an extra space in nature, for leisure but also for subsistence agriculture. 
While playing the right cards, rural heritage rich communities could become winners of the COVID-19 in what concerns repopulation, saving the local heritage and no least social and economic development.

In order to achieve this, rural heritage rich communities need to use existing economic models in their favour, like the newly developed Low Touch Economy model and the not so old Social Economy model. These, intertwined, bring into the community their individual characteristics that combined, create powerful tools for development: innovative spirit, adaptability, social responsibility and resilience.

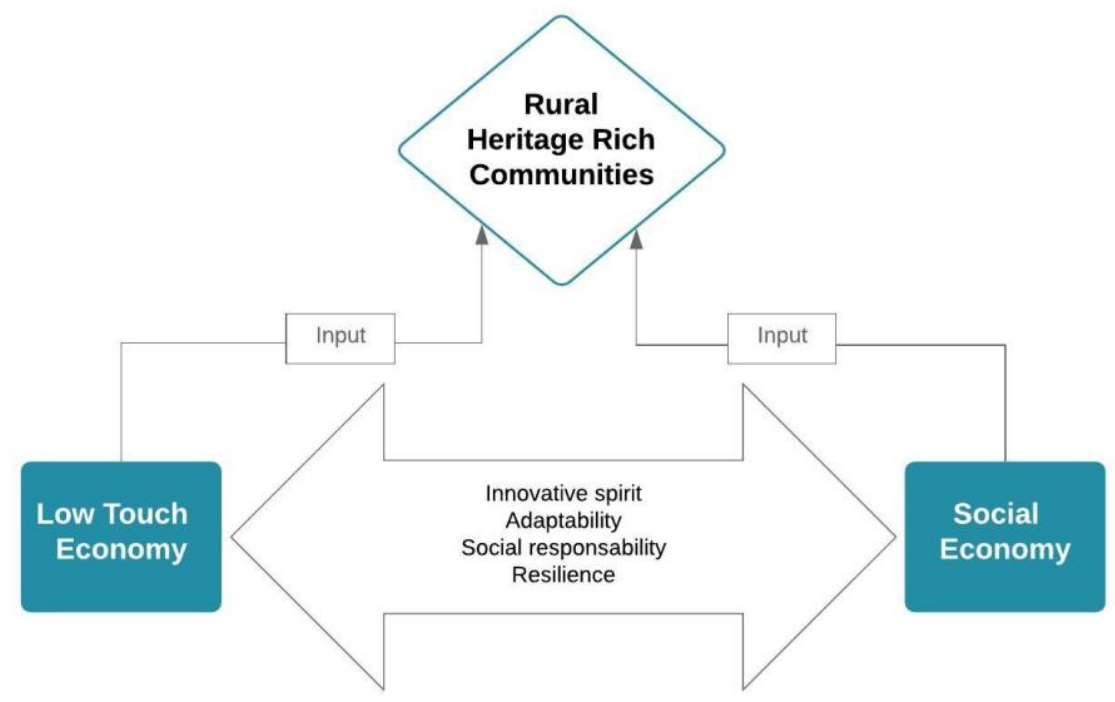

Figure 5. Relations between Rural Heritage Rich Communities, Low Touch Economy and Social Economy. Source: Authors own elaboration.

This combined model assumes the switch from defence to offence, in a low touch environment, while being fully connected to the local community in order to deal with crises.

The new combined framework for transforms the Low Touch Economy from an exclusive business oriented model to a resilience and community support model. The assessment of the impact is combined with assessment of threats and opportunities, development of a strategy is made with the support of local community in order to deal with the specific social problems, and then the whole community will be going on the offence and make it happen. 
Low Touch Economy

Switch from defense to

offence, in a low touch

environment:

- Assess the impact

-Develop the strategy

- Go on offense

-Make it happen

\section{Social Economy}

Strong communities dealing

with crises

- Assess the threats/ opportunities

- Gather along the community

- Strategies over dealing with the social problems

- Make it happen

Figure 6. Framework of the combined economic model.

Source: Authors own elaboration.

This proposed framework of the combined economic model can be a response not only to COVID-19 crisis, but also to crises generated by natural disasters, economic downfalls or any other future dangers.

\section{Arguments to argue the thesis}

A main problem in the process of recovery and development in rural heritage rich communities not only in the context of COVID-19 pandemic is the lack of state support, which should normally guarantee economic stability and provide resources necessary for the local development [15].

At international level, states have declared that they are preparing assistance packages for the highest hit sectors of their economies. However, not all of them will overcome the state of proposal and reach the vulnerable, and not all of them will have a real impact on long term, according to those declared against state's involvement in the economy.

On one side, rural heritage rich communities could positively benefit from financial assistance in what concerns first hand adaptability to the new social and health restrictions. 
Anamaria BUCACIUC, ... | Lumen Proceedings 13 | NCOE4.0 2020

\section{Dismantling the arguments against}

Even though the state assistance is welcomed but it cannot be depended on, the combined model between Low Touch Economy and Social Economy offer the right tools for the resilience of rural heritage rich communities.

While using their local resources and innovative capacities and carrying on with the redesign process in a community sensible manner, the strong connectivity with the local community could compensate the lack of sufficient state support.

\section{Conclusions}

Thus, we have to keep into perspective the fact that COVID-19 crisis is here to stay for a longer period, and that the countless threats scientists preached about are more tangible to our today's perception. That is why we have to start connecting the dots between different economic theories that come each with innovative practices and solutions adapted to specific environments.

In this paper we have seen that the intertwining of elements from the low touch economy and social economy have a potential of supporting the recovery and further development of rural heritage rich communities. This can be made through the assessment of impact, development of strategies, going on the offence and implementation of the developed strategies, while always using innovation in order to help the social cohesion, the creation of jobs and generation of sustainable social transformations.

Further research perspectives could explore different types of development of rural heritage rich communities from tourism perspective and in accordance with low touch economy and social economy, though innovative tourism models like virtual rural heritage tourism, augmented rural heritage tourism, tourism for change and tourism for impact.

\section{Acknowledgement}

This work was supported by a grant of the Romanian Ministry of Research and Innovation, CCCDI-UEFISCDI, project number PN-III-P11.2-PCCDI-2017-0884/56PCCDI/03.04.2018, within PNCDI III. 
Anamaria BUCACIUC, ... | Lumen Proceedings 13 | NCOE4.0 2020

\section{References}

[1] International Monetary Fund. World Economic Outlook, January 2020, Tentative Stabilization, Sluggish Recovery? World Econ Outlook. 2020;1-10.

[2] Bucaciuc A, Prelipcean G. Social entrepreneurship models for cherishing the rural architectural heritage. Architektur und Tourismus im Bauhausjahr 2019 Weimar | Dessau | Berlin Conference P roceedings; 2019.

[3] World Health Organiziation. WHO Coronavirus Disease (COVID-19) Dashboard [Internet]. 2020. Available from: https://covid19.who.int/

[4] Cucinotta D, Vanelli M. WHO declares COVID-19 a pandemic. Acta Biomed. 2020; 91(1):157-60.

[5] Official Journal of the European Union. Opinion of the European Economic and Social Committee on 'The contribution of Europe's rural areas to the 2018 Year of Cultural Heritage ensuring sustainability and urban/rural cohesion' [Internet]. Brussels; 2018. Available from: https://eurlex.europa.eu/legalcontent/EN/TXT/HTML/?uri=CELEX:52018IE1641\&rid=10

[6] OECD. Innovation and modernising the rural economy from the Organisation for Economic Co-operation and Development; 2012.

[7] Romanian American Foundation. RAF - Economie Rurala [nternet]. Available from: https://www.rafonline.org/strategic/economie-rurala/?cnreloaded $=1$

[8] Bejan G, Budeș M, Iacob A. Distanțarea socială la țară. Cum respectă carantina totală oamenii din câteva sate din Giurgiu și Teleorman. HotNews.ro Internet]; 2020; Available from: https://www.hotnews.ro/stiri-coronavirus23766039-coronavirus-romania-cum-respecta-carantina-totala-oamenii-dinmediul-rural.htm

[9] FAO. COVID-19 and rural poverty: Supporting and protecting the rural poor in times of pandemic [Internet]. 2020. Available from: http:/ /www.fao.org/3/ca8824en/CA8824EN.pdf

[10] Khan T. How covid-19 is impacting the rural market. The Financial Express [Internet]; 2020; Available from: https://www.financialexpress.com/brandwagon/how-covid-19-is-impactingthe-rural-market/1940102/

[11] Mendell M. Three pillars of the social economy. In: Amin A, editor. The social economy. II. London and New York: Zed Books; 2009. p. 176-207.

[12] Vlasceanu M. Economie sociala si antreprenoriat. O analiza a sectorului nonprofit. Polirom; 2010.

[13] Fantasia A. Unlocking the potential of the social economy is one way to ensure a COVID-19 recovery. Euronews [Internet]. 2020; Available from: https://www.euronews.com/2020/05/13/unlocking-the-potential-of-thesocial-economy-is-one-way-to-ensure-covid-19-recovery-view 
Anamaria BUCACIUC, ... | Lumen Proceedings 13 | NCOE4.0 2020

[14] Boart of Innovation. Welcome to the Low Touch Economy - Board of Innovation [Internet]; 2020. Available from: https://www.boardofinnovation.com/low-touch-economy/

[15] Chaşovschi C, Bordeianu O, Clipa D. Entrepreneurial Culture in Transition Economies. The case of Romania and Republic of Moldova. Procedia Econ Financ. 2014; 15(14):1507-14. 